\title{
INDEBTEDNESS OF STATUTORY CITIES IN THE CZECH REPUBLIC
}

\author{
[Zadluženost statutárních měst v České republice] \\ Eva Lajtkepová ${ }^{1}$ \\ ${ }^{1}$ Vysoké učeni technické v Brně, Fakulta podnikatelská, Kolejní 2906/4, 61200 Brno \\ Email:lajtkepova@fbm.vutbr.cz
}

\begin{abstract}
In the Czech Republic municipalities are seen, in accordance with the Constitution, as the basic element of local government; their roles, tasks and operations governed by the relevant legal regulations. Municipalities have lower powers to raise taxes and so their incomes are largely dependent on transfers from the state budget. The aim of this text is to investigate the possible dependence of indebtedness (expressed as debt per capita) on the size of the municipality (according to the number of inhabitants) and the fragmentation of local government (measured with the aid of the Herfindahl-Hirschman Index). We examined this dependence in data on the statutory cities of the Czech Republic, using the methods of correlation analysis and the chi-squared test. However on the basis of the results we can state that the only statistically significant correlations are between debt per capita and the size of the city, while all the other results were statistically insignificant.
\end{abstract}

Keywords: indebtedness, local government, municipality, statutory city.

JEL classification: H72

Doručeno redakci: 18.9.2017; Recenzováno: 2.10.2017; 4.10.2017; Schváleno k publikování: 13.12.2017

\section{Úvod}

Obce v České republice jsou v souladu s čl. 99 ústavního zákona považovány za základní územně samosprávné celky, každá obec je vždy součástí vyššího územně samosprávného celku - kraje. Režim působnosti a pravomoci obcí a krajů vychází z tzv. smíšeného modelu veřejné správy (Průcha 2011, s. 23), což umožňuje vzájemnou návaznost jejich činnosti. Postavení a úkoly obcí a jejich orgánů upravuje zákon č. 128/2000 Sb., o obcích (obecní zřízení), základní rámec hospodaření obcí vymezuje potom zákon č. 250/2000 Sb., o rozpočtových pravidlech územních rozpočtů.

Finanční hospodaření obcí se řídí př́islušným ročním rozpočtem, který vychází ze střednědobého výhledu rozpočtu. Rozpočet je sestavován zpravidla jako vyrovnaný; jako schodkový ho lze schválit jen $\mathrm{v}$ př́ípadě, že tento schodek může být uhrazen $\mathrm{z}$ finančních prostředků $\mathrm{z}$ let minulých, smluvně zajištěnou půjčkou nebo úvěrem, výnosem z vydaných dluhopisů nebo návratnou finanční výpomocí (§ 4 zákona 250/2000 Sb.). Obce v České republice mají velmi nízkou vlastní daňovou pravomoc: samy mohou (v rámci zákona) pouze rozhodovat o dani z nemovitých věcí a o místních poplatcích. Obce jsou tedy dosti závislé na transferech ze státního rozpočtu, především na přerozdělovaném podílu sdílených daní (DPH, dani z prŕijmů právnických osob a dani z prŕijmů fyzických osob) (zákon č. 243/2000 Sb.).

Kontrola hospodaření obcí probíhá jako vnitřní a vnější. Nejvyšším orgánem vnitřní kontroly je zastupitelstvo obce, vnější kontrola je povinně každý rok provedena jako přezkoumání hospodaření obce auditorem nebo krajským úruadem (dle velikosti obce). Dalším způsobem kontroly hospodaření obcí je monitoring, který provádí Ministerstvo financí ČR. To každoročně vypočítává za všechny obce soustavu informačních a monitorujících ukazatelů a výpočty vyhodnocuje. Pokud Ministerstvo financí identifikuje u některých obcí potenciální 
problémy, jsou nejdříve na tuto skutečnost upozorněny dopisem ministra financí, ale následně jim je nabídnuta pomoc s analýzou situace. Jinými slovy, Ministerstvo financí ČR nemá ve skutečnosti účinný nástroj, kterým by omezovalo špatné hospodaření obcí, př́padně regulovalo jejich zadluženost. Snad jedinou výstrahou pro obce může být ustanovení zákona o obcích, které výslovně stanovuje, že za závazky obcí stát neručí (i když je může převzít smluvně) (§ 38 zákona č. 128/2000 Sb.). Český právní řád ale nikde neřeší situaci, pokud by stát závazky obce odmítnul převzít: tj. není popsán a uzákoněn postup při insolvenci obce. Pokusem o regulaci zadluženosti obcí je po velkých diskusích schválený zákon č. 23/2017 Sb., o pravidlech rozpočtové odpovědnosti, který by měl nabýt účinnosti od ledna 2018.

\section{Krátký přehled související literatury}

Zadluženost se v posledních letech stala jedním z nejčastěji zpracovávaných výzkumných témat oblasti veřejných financí. I když se většímu zájmu teoretických i empirických statí zpravidla těší v různých souvislostech zadluženost států - zvláště zemí EU (Baldi a Staehr 2016), (Mencinger et al. 2014), (Greiner 2012), postupně se pozornost přesouvá i k zadluženosti regionů a municipalit. Je to pochopitelné - zadluženost nižších územně samosprávných celků je jednak součástí veřejného dluhu státu, ale zároveň jejich hospodaření zcela bezprostředně ovlivňuje běžný život každého občana.

Prací, které se zabývají zadlužením municipalit (případně regionů) tedy přibývá, jsou dosti diferencované, opět teoretického i čistě empirického charakteru. Podle hlavního zaměření je můžeme rozdělit do několika skupin: a) práce zabývající se ratingem zadlužených subjektů, b) práce hledající limity zadlužení municipalit a regionů, c) práce hledající a popisující různé faktory, které toto zadlužení ovlivňují. Zde jsou zvláštní podskupinou publikací práce, zkoumající politicko-ekonomický cyklus na místní úrovni. Velmi často jsou v textech reflektovány různé souvislosti s fiskálním federalismem, př́ípadně s fiskální decentralizací.

Obecně se teorie veřejné ekonomie k zadlužení (at' státu, tak regionů i municipalit) nestaví zamítavě (Buchanan 1998), (Musgrave a Musgraveová 1994): pouze doporučuje, aby běžné výdaje byly financovány $z$ běžných příjmů (samozřejmě především daňových), kapitálové výdaje z př́ijmů kapitálových - včetně úvěrů, případně př́ijmů z vydaných dluhopisů. Nicméně zadlužení (at' formou přijatého úvěru, tak vydáním dluhopisů) je zpravidla připuštěno jen ve spojení s pořízením investic. Dokonce doporučují právě financování veřejných investic dluhem, který bude splácen delší období (kdy dochází ke splácení dluhu současně s využíváním investice), aby byla zajištěna mezigenerační spravedlnost (ibid, s. 513). Podobný názor, tj. dluhově financovat místní kapitálové projekty, mají např. i HoltzEakin (1991) a Cropf a Wendel (1998). Mezigenerační spravedlnost je také některými autory (např. Stavins et al. 2003) spojována s udržitelností dluhu. I když Botoc et al. (2011) upozorňují na jistou vágnost a neujasněnost pojmu "udržitelnost dluhu", lze ho popsat jako schopnost a ochotu (místní) vlády dluh splácet a v budoucnu dluh dále nezvyšovat. Bolívar et al. (2014) na základě empirického výzkumu pro podmínky vybraných španělských municipalit konstatují, že na udržitelnost municipálních dluhů má vliv jak výsledek ročního hospodaření, tak i úroveň finanční kontroly.

Kiewiet a Szakaty (1996) na základě analýzy dat z USA docházejí k závěru, že úroveň zadlužení municipalit byla ovlivňována dvěma faktory: výší osobního př́ijmu v přepočtu na jednoho obyvatele a levostrannou orientací vlády. Vliv různých socioekonomických faktorů (např. populace, podíl imigrantů na populaci, transfery a daňové př́ijmy apod.) na úroveň dluhu na jednoho obyvatele připouštějí i Guillamón et al. (2011). Stejní autoři (2013) znovu potvrzují vliv populace na úroveň výdajů, zároveň upozorňují na to, že se tyto výdaje zvyšují 
vždy rok před municipálními volbami. To dle nich potvrzuje domněnku o politickoekonomickém cyklu ve Španělsku na místní úrovni. Politicko-ekonomický cyklus pro podmínky místní úrovně Portugalska považují za prokazatelný i Veiga a Veiga (2007).

Vliv více faktorů na úroveň zadlužení, mezi nimiž je mj. populace, fiskální autonomie (vlastní př́ijmy), dohled centrální vlády i místní politické faktory, identifikovali Hájek a Hájková (2009) pro podmínky 452 obcí Pardubického kraje v období let 2002 - 2006. Naopak např. vliv výše osobního př́jmu na dluh se v jejich analýze ukázal jako statisticky nevýznamný.

Hypotézu, že slabá vláda (tj. více fragmentovaná, složená z více stran v koalici) vede k vyššímu zadlužení (Roubini a Sachs 1989), testovali Ashworth et al. (2005) na datech 298 vlámských municipalit v letech 1977 - 2000. Došli k názoru, že slabá vláda z dlouhodobého hlediska nemá na zadlužení vliv, ale v krátkém období skutečně dluh zvyšuje. Tuto hypotézu ale nepotvrzují Guillamón et al. (2011), kteří naopak pro podmínky Španělska poukazují na skutečnost, že slabší vlády měly nižší úrovně zadlužení.

S poukazem na vliv populace na úroveň zadlužení nižších vlád se setkáváme i u dalších autorů. Např. Rivers a Yates (1997) teoreticky objasňují, že růst populace má za následek růst požadavků na místní veřejný sektor, a tedy ve svém důsledku vede k vyššímu zadlužení. Podobnou myšlenku najdeme i u Wei-Te (1995) pro specifické podmínky municipalit zaměřených na cestovní ruch. Ten sice podporuje vyšší ekonomický růst, ale zároveň klade vyšší nároky na místní veřejný sektor (veřejné služby a infrastrukturu). Rodden (2002) se domnívá, že nižší vládní úrovně mohou mít dlouhodobě vyrovnané rozpočty, jen pokud centrální vláda stanoví významné restrikce pro jejich zadlužování (resp. možnosti půjčování), nebo lokální vlády mají velkou daňovou a dluhovou autonomii. Naopak jsou-li nižší vládní úrovně závislé na dotacích z centrálních rozpočtů a samy nemají př́liš velkou možnost půjčování, dlouhodobé deficity u nich přetrvávají. Baskaran (2010) považuje snižování veřejného zadlužení za prokazatelný důsledek vysokého stupně výdajové decentralizace, naopak daňová decentralizace ke snížení veřejného zadlužení dle tohoto autora nevede.

\section{Cíl textu, zdroje dat a metodologie}

Předmětem předloženého textu je zadluženost statutárních měst v České republice. Hlavním cílem článku je zjištění možné závislosti zadluženosti (vyjádřené jako zadluženost/obyv.) na velikosti statutárních měst (podle počtu obyvatel) a na fragmentaci místní vlády (tj. zastupitelstva). Tyto dva faktory byly zvoleny na základě podnětů z literatury (Ashworth et al. 2005), (Guillamón et al. 2011), (Guillamón et al. 2013), (Hájek a Hájková 2009), (Rivers a Yates 1997), (Roubini a Sachs 1989). Ostatně i Ministerstvo financí ČR se domnívá, že zadlužení municipalit v ČR souvisí s jejich velikostí: zatímco u nejmenších obcí (200-500 obyvatel) není zadlužení př́liš časté, velká města jsou (se skutečně malými výjimkami) zadlužena všechna ${ }^{1}$.

V České republice je 25 statutárních měst, která jsou taxativně vyjmenována $\mathrm{v} \S 4$ zákona 128/2000 Sb. Statutárními městy jsou největší města ČR: i když jejich počet je relativně malý (je to ani ne $0,5 \%$ z celkového počtu obcí v ČR), žije v nich téměř jedna čtvrtina obyvatel (bez Prahy) a tvoří poměrně kompaktní soubor. Připomínáme, že Praha není ve zkoumaném vzorku započítána: má totiž zvláštní status, je to současně město i kraj. Navíc se Praha natolik odlišuje od ostatních měst ČR (velikostí, ekonomickým potenciálem apod.), že její zahrnutí do zkoumaného vzorku by výsledky nutně významně zkreslilo.

\footnotetext{
${ }^{1}$ http://www.mfcr.cz
} 
Vzhledem ke zkoumané problematice bylo možné využít pouze sekundárních zdrojů: data o počtu obyvatel a zadlužení statutárních měst byla převzata $\mathrm{z}$ monitoringu Ministerstva financí $\mathrm{C}^{2}$. Údaje o výsledcích voleb a složení zastupitelstev potom z oficiálních webových stránek o volbách ${ }^{3}$.

Protože zadluženost může samozřejmě meziročně kolísat, pro analýzu byla u všech statutárních měst vypočtena průměrná zadluženost/obyv. za období 2010 - 2015. Toto období nebylo zvoleno náhodně: a) projevily se v něm již plně problémy ekonomické recese, kdy se města a obce obtížně vyrovnávaly s klesajícími transfery ze státního rozpočtu z celostátně vybraných daní, b) v roce 2012 se změnilo rozpočtové určení daní, kdy byl nadále pro přerozdělení obcím určen nižší podíl z celostátně vybrané $\mathrm{DPH}, \mathrm{c})$ dvakrát se konaly volby do obecních zastupitelstev (2010 a 2014), tj. mohl být eliminován i př́ípadný vliv „zděděného“ zadlužení z let minulých.

Údaje o počtu obyvatel statutárních měst byly použity opět jako průměr z let 2010 - 2015 .

Fragmentaci lokální vlády (zastupitelstva) jsme sledovali pomocí Herfindahl-Hirschmanova indexu (dále jen HHI) (srov. Hájek a Hájková 2009), kde „podíl na vládě“ je vyjádřen podílem zastupitelů príslušné politické strany na celkovém počtu zastupitelů. Vycházíme z podmínek ČR, kdy rozpočet (včetně jeho případného deficitu), ale i rozhodnutí o zadlužení (přijetí úvěru, vydání komunálních dluhopisů, přijetí finanční výpomoci z jiných fondů rozpočtové soustavy) musí schválit celé zastupitelstvo. Dodejme, že HHI nevyjadřuje politické zaměření zastupitelstva (ve smyslu pravo-levého politického spektra), ale jen jeho kompaktnost či roztř́šštěnost. Pokud je zastupitelstvo složeno z mnoha politických subjekti̊, kdy každý z nich má svoji agendu, může být velmi obtížné (zvláště ve velkých městech jako jsou statutární města) se shodnout na prioritách i jejich naplňování. V HHI byly zohledněny výsledky obou voleb do obecních zastupitelstev $(2010,2014)$ ve sledovaném období.

Data jsou zpracována pomocí standardních metod popisné statistiky, korelační analýzou a pomocí chí-kvadrát testu. Vzhledem k malému rozsahu vzorku (25 statutárních měst) jsme použili Fisherův exaktní test.

\section{Výsledky a diskuse}

Obce v České republice (včetně jimi zřizovaných organizací) vykázaly ke konci roku 2015 celkový dluh ve výši 86,9 mld. Kč, přičemž největší váhu v zadluženosti mají bankovní úvěry a emitované komunální dluhopisy. Z celkového počtu 6248 obcí v ČR bylo v roce 2015 zadluženo 3255 obcí (tj. 52,1 \%). Podle zatím neúčinného zákona o pravidlech rozpočtové odpovědnosti pro územně samosprávné celky (dluh k průměru prŕijmů za poslední čtyři roky nesmí překročit $60 \%$ ) vyhovuje kritériím $92 \%$ obcí, podle monitoringu Ministerstva financí ČR hospodaří s vyšší mírou rizika dokonce jen 28 obcí. $^{4}$

\footnotetext{
${ }^{2}$ http://www.monitor.statnipokladna.cz

${ }^{3}$ http://www.volby.cz

${ }^{4}$ http://www.mfcr.cz
} 
Tabulka 1: Zadluženost obcí v ČR v letech $2004-2015$ (mld. Kč)

\begin{tabular}{|l|c|c|c|c|c|c|c|}
\hline & $\mathbf{2 0 0 4}$ & $\mathbf{2 0 0 6}$ & $\mathbf{2 0 0 8}$ & $\mathbf{2 0 1 0}$ & $\mathbf{2 0 1 2}$ & $\mathbf{2 0 1 4}$ & $\mathbf{2 0 1 5}$ \\
\hline Úvěry & 38,5 & 47,1 & 47,4 & 59,9 & 68,3 & 67,7 & 66,1 \\
\hline Komunální dluhopisy & 23,9 & 22,9 & 22,7 & 15,8 & 13,8 & 11,8 & 10,7 \\
\hline Př́ijaté finanční výpomoci & 12,4 & 10,9 & 10,0 & 7,6 & 7,9 & 9,4 & 10,1 \\
\hline Celkem & $\mathbf{7 4 , 8}$ & $\mathbf{8 0 , 9}$ & $\mathbf{8 0 , 1}$ & $\mathbf{8 3 , 3}$ & $\mathbf{9 0 , 0}$ & $\mathbf{8 8 , 9}$ & $\mathbf{8 6 , 9}$ \\
\hline
\end{tabular}

Zdroj: Ministerstvo financí ČR (dostupné na http://www.mfcr.cz/cs/verejny-sektor/uzemnirozpocty/zadluzenost-uzemnich-rozpoctu/2015/zadluzenost-uzemnich-rozpoctu-v-roce-26255)

Jiný pohled ale získáme, pokud na celkové zadluženosti budeme sledovat podíl čtyř největších měst (Praha, Brno, Plzeň, Ostrava):

Tabulka 2: Podíl čtyř největších měst na celkové zadluženosti obcí ČR (\%)

\begin{tabular}{|c|c|c|c|c|c|c|c|c|}
\hline 2 & 2004 & 2006 & 2008 & 2010 & 2012 & 2014 & 2015 & \\
\hline Podíl čtyř největších měst & 61,4 & 58,6 & 57,2 & 48,1 & 50,6 & 51,0 & 50,4 & \\
\hline
\end{tabular}

Podívejme se nyní (Tabulka 3:) na základní výsledky popisné statistiky pro soubor 25 statutárních měst:

Tabulka 3: Výsledky popisné statistiky

\begin{tabular}{|l|c|c|c|}
\hline Ukazatel & $\begin{array}{c}\text { Zadluženost/obyv. } \\
\text { (Ǩc/obyv.) }\end{array}$ & HHI & Počet obyvatel \\
\hline MIN & 0 & 1436 & 44297 \\
\hline MAX & 20817 & 4226 & 375941 \\
\hline Průměr & 8358 & 2421 & 92592 \\
\hline Medián & 7646 & 2302 & 67254 \\
\hline Směrodatná odchylka & 5192,38 & 695,85 & 79669,11 \\
\hline Variační koeficient & 62,12701 & 28,74221 & 86,04364 \\
\hline Dolní kvartil & 5342 & 2008 & 50545 \\
\hline Horní kvartil & 9556 & 2638 & 93900 \\
\hline
\end{tabular}

Pozn. HHI = Herfindahl-Hirschmanův index

Zdroj: Vlastní výpočet dle údajů Ministerstva financí ČR (www. mfcr.cz) a oficiálních stánek voleb v ČR (ww.volby.cz)

Z těchto informací můžeme vidět, že se statutární města ČR ve své zadluženosti/obyv. velmi liší: na jedné straně město Teplice, které je dlouhodobě nezadlužené (údaj MIN), na straně druhé Liberec se zadlužeností 20817 CZK/obyv. (údaj MAX). Zajímavá je hodnota variačního koeficientu: svědčí o značné nesourodosti statutárních měst $z$ hlediska zadlužení/obyv. Ostatně i hodnota směrodatné odchylky naznačuje totéž: absolutní variabilita měst z hlediska zadlužení/obyv. je dosti vysoká. Můžeme tedy říci, že vypovídací schopnost jak vypočteného aritmetického průměru, tak mediánu není př́lišs velká - oba ukazatele jsou dosti ovlivněny extrémními hodnotami.

Velmi různorodý je tento soubor i z hlediska velikosti měst (podle počtu obyvatel): zde hodnoty směrodatné odchylky i variačního koeficientu svědčí o velké nesourodosti. Ostatně i extrémní hodnoty jsou od sebe značně vzdálené: hodnota minima je pro město Mladá Boleslav, maxima pro Brno. 
Pouze hodnoty Herfindahl-Hirschmanova indexu se u všech měst od sebe liší méně: většinou se totiž do městských zastupitelstev po volbách dostane alespoň pět nebo šest politických stran a uskupení, tj. jejich podíl na moci je potom relativně malý. Extrémním př́padem je Hradec Králové (v Tabulce 3: hodnota MIN), kdy bylo v zastupitelstvu př́tomno osm stran a hnutí. Zcela výjimečně je počet stran menší a některá ze stran má absolutní většinu (tento př́pad je Karviná, hodnota HHI je v Tabulce 3: MAX). Proto je soubor z hlediska fragmentace místní vlády relativně sourodý.

\section{Korelační analýza}

Pro zjištění síly závislosti mezi pořadími hodnot jednotlivých proměnných jsme nejprve použili Spearmanův koeficient pořadové korelace. Výsledky jsou následující:

Tabulka 4: Spearmanův korelační koeficient

\begin{tabular}{|l|c|c|c|}
\hline Proměnná & Zadluženost/obyv. & HHI & Počet obyvatel \\
\hline Zadluženost/obyv. & 1,000000 & $-0,043077$ & 0,603077 \\
\hline HHI & $-0,043077$ & 1,000000 & $-0,112308$ \\
\hline Počet obyvatel & 0,603077 & $-0,112308$ & 1,000000 \\
\hline
\end{tabular}

Pozn. Označené korelace jsou významné na $p<0,05$

Zdroj: Vlastní výpočet na základě údajů Ministerstva financí ČR a volebních výsledků

$\mathrm{Na}$ základě vypočtených hodnot Spearmanova koeficientu můžeme konstatovat statisticky významnou středně silnou shodu pořadí mezi zadlužeností/obyv. a velikostí města (podle počtu obyvatel). Přesto možná jistým překvapením je nižší hodnota vypočteného koeficientu, než jsme očekávali: $v$ další analýze plánujeme zjišt'ovat statistickou závislost mezi těmito veličinami. Nicméně se ale touto relativně jednoduchou metodou potvrzují pro podmínky statutárních měst ČR ty názory, které označují velikost města za jeden z faktorů jeho zadlužení (Guillamón et al. 2013), (Hájek a Hájková 2009), (Rivers a Yates 1997).

Vzhledem k tomu, že se některá ze statutárních měst dále člení na městské obvody či městské části s vlastní samosprávou, byl doplňkově vypočten i korelační koeficient mezi dvojicí proměnných zadluženost/obyv. a počet obvodů/částí. Hodnota vypočteného korelačního koeficientu $(0,422787)$ naznačila mezi těmito proměnnými slabší středně silnou závislost, tj. lze předpokládat, že počet městských obvodů či částí může mít na zadlužení statutárních měst jistý vliv. Nicméně připomeňme, že na samosprávné městské obvody či městské části se člení především největší (a nejzadluženější) statutární města (napřs. Brno, Ostrava či Plzeň), proto uvedený výsledek spíše jen doplňuje náš pohled na vztah mezi zadlužeností/obyv. a velikostí města.

Skutečným překvapením jsou ale hodnoty vypočteného Spearmanova koeficientu pro pár proměnných zadluženost/obyv. a Herfindahl-Hirschmanův index (HHI). Očekávali jsme totiž statisticky významnou alespoň středně silnou shodu opačných pořadí, která by svědčila o tom, že čím větší je zadluženost, tím je místní vláda fragmentovanější (rozuměj - slabší) (Ashworth et al. 2005), (Roubini a Sachs 1989). Hodnota koeficientu sice se záporným znaménkem, ale velice blízká nule tento předpoklad nepotvrzuje, ale zároveň ani nepotvrzuje názor opačný, tzn. že slabé vlády mají zadlužení nízké (Guillamón et al. 2011). Jinými slovy, pro podmínky statutárních měst ČR nelze přijmout jednoznačný závěr, že by vyšší fragmentace místní vlády (tj. složení zastupitelstva $\mathrm{z}$ více politických uskupení) vedla k vyššímu nebo naopak nižšímu zadlužení. Názor (např. Hájek a Hájková 2009), že se všechny politické subjekty snaží prosadit svoje priority, což při jejich větším počtu v zastupitelstvu vede celkově k vyšším investicím (i vyššímu zadlužení), se u statutárních 
měst ukázal jako neudržitelný, stejně ale tak i názor, že města více zadlužují vlády se silnou majoritou jedné politické strany a méně početnou opozicí (Guillamón et al. 2011).

I když hodnota koeficientu mezi párovými proměnnými Herfindahl-Hirschmanův index a velikost města nebyla prvořadě v centru naší pozornosti, její výsledek je též zajímavý: hodnota blízká nule nenaznačuje souvislost mezi fragmentací místní vlády a počtem obyvatel města. Snad jen záporné znaménko může vést k domněnce, že do zastupitelstev větších měst se dostává více politických subjektů, tj. jsou potom roztříštěnější.

Spíše pro úplnost analýzy jsme ještě vypočetli Kendallův korelační koeficient, nicméně výsledky (viz Tabulka 5:) jen potvrdily již vyslovené závěry. Jako statisticky významná se projevila jen korelace mezi párem proměnných zadluženost/obyv. a velikost města, ostatní výsledky byly neprůkazné a statisticky nevýznamné.

Tabulka 5: Kendallovy korelace

\begin{tabular}{|l|c|c|c|}
\hline Proměnná & Zadluženost/obyv. & HHI & Počet obyvatel \\
\hline Zadluženost/obyv. & 1,000000 & $-0,026667$ & 0,406667 \\
\hline HHI & $-0,026667$ & 1,000000 & $-0,060000$ \\
\hline Počet obyvatel & 0,406667 & $-0,060000$ & 1,000000 \\
\hline
\end{tabular}

Pozn. Označené korelace jsou významné na p $<0,05$

Zdroj: Vlastní výpočet na základě údajů Ministerstva financí ČR a volebních výsledků

\section{Závislost mezi zadlužeností města, jeho velikostí a fragmentací místní vlády}

Pro zkoumání statistické závislosti mezi proměnnými (vždy obě párové proměnné jsou numerické) jsme zvolili chí-kvadrát test. Vzhledem k nízkému počtu př́ipadů (25) byly některé četnosti v kontingenčních tabulkách menší než 5, proto jsme museli použít Fisherův exaktní test.

I když výsledky korelační analýzy nedávají př́liš velkou naději na zjištění významné závislosti, jako výchozí jsme přesto formulovali tyto dva předpoklady:

- Zadlužení/obyv. závisí na velikosti města (dle počtu obyvatel),

- Zadlužení/obyv. závisí na fragmentaci vlády (dle vypočteného HHI).

Výsledky analýzy jsou následující (Tabulka 6: a Tabulka 7:):

Tabulka 6: Výsledky pro pár proměnných zadluženost/obyv. a velikost města

\begin{tabular}{|l|l|l|}
\hline Chí-kvadrát & 4,59 & $\mathrm{p}=0,0322$ \\
\hline V-kvadrát & 4,40 & $\mathrm{p}=0,0358$ \\
\hline Fisherovo $\mathrm{p}$, jednostranné & & $\mathrm{p}=0,0433$ \\
\hline Fisherovo $\mathrm{p}$, oboustranné & & $\mathrm{p}=0,0810$ \\
\hline
\end{tabular}

Zdroj: Vlastní výpočet na základě údajů Ministertva financí ČR

I když korelační analýzou byla zjištěna statisticky významná (na $5 \%$ hladině významnosti) korelace mezi zadlužeností/obyv. a velikostí města, zde se tato závislost nepotvrdila (viz Fisherovo oboustranné $\mathrm{p}$ : neplatí, že vypočtené $\mathrm{p}<0,05)$. Tj. náš původně vyslovený předpoklad a domněnka, že na zadluženost města má vliv mj. i jeho velikost, který byl v souladu s výsledky dalších studií (Guillamón et al. 2013), (Hájek a Hájková 2009), (Rivers a Yates 1997), se tímto testem nepotvrdil. Pro statutární města v České republice se tedy nepotvrdila tímto testem statisticky významná závislost mezi jejich zadlužeností/obyv. a jejich velikostí (dle počtu obyvatel). 
Tabulka 7: Výsledky pro pár proměnných zadluženost/obyv. a fragmentace vlády (HHI)

\begin{tabular}{|l|c|l|}
\hline Chí-kvadrát & 1,73 & $\mathrm{p}=0,1882$ \\
\hline V-kvadrát & 1,66 & $\mathrm{p}=0,1973$ \\
\hline Fisherovo $\mathrm{p}$, jednostranné & & $\mathrm{p}=0,1831$ \\
\hline Fisherovo $\mathrm{p}$, oboustranné & & $\mathrm{p}=0,2406$ \\
\hline
\end{tabular}

Zdroj: vlastní výpočet na základě údajů Ministertva financí ČR a volebních výsledků

Vzhledem k výsledkům korelační analýzy jsme v tomto př́padě byli již před výpočtem velice opatrní a skeptičtí: bylo spíše jasné, že výsledky nám jen s pomocí jiné metody potvrdí výše uvedenou skutečnost, že pro podmínky statutárních měst v ČR nelze uvažovat o jakékoliv závislosti mezi zadlužeností/obyv. a fragmentací vlády (dle HHI). A je tomu skutečně tak: vypočtená hodnota oboustranného Fisherova $\mathrm{p}$ je natolik vysoká (opět neplatí, že vypočtené $\mathrm{p}<0,05$ ), že ani vzdáleně nedovoluje uvažovat o jakékoliv závislosti či alespoň souvislosti mezi těmito proměnnými - na rozdíl od zahraničních studií (Ashworth et al., 2005), (Guillamón et al. 2011), (Roubini a Sachs 1989). Př́čin, proč se zde neprojevila jakákoliv souvislost (nebo dokonce závislost), může být celá řada (a každá z nich by zasluhovala vlastní zkoumání): malý rozsah zkoumaného souboru, kratší časová řada, specifické politické podmínky ČR, rozsah pravomocí zastupitelstev apod.

\section{Závěr}

Shrňme tedy závěry z našich analýz především ve vztahu k původnímu cíli textu: tj. ke zjištění možné závislosti zadluženosti/obyv. na velikosti statutárních měst (podle počtu obyvatel) a na fragmentaci místní vlády.

Nejdříve je ale třeba poznamenat, že zadluženost obcí se obecně v České republice nepocit’uje jako nijak mimořádně palčivý ekonomický problém. Dle údajů Ministerstva financí ČR je sice zadluženo více než $52 \%$ z celkového počtu obcí, ale polovina celkového zadlužení připadá na čtyři největší česká města. I když je mezi obcemi v zadlužení velký rozdíl, dá se přesto říci, že hospodaření českých obcí je poměrně uvážlivé a pokud se zadlužují, tyto prostředky směřují na zlepšování místní infrastruktury, školství apod.

Předmětem naší pozornosti byla zadluženost statutárních měst v ČR. Na základě studia literatury a souvisejících zdrojů (Ashworth et al. 2005), (Guillamón et al. 2013), (Hájek a Hájková 2009), (Rivers a Yates 1997), (Roubini a Sachs 1989) jsme se pokusili na tomto souboru ověřit, zda existuje i v podmínkách ČR závislost mezi zadlužeností/obyv. a velikostí (podle počtu obyvatel) a zadlužeností/obyv. a fragmentací místní vlády (zastupitelstva). S použitím korelační analýzy jsme dospěli k opatrnému závěru, že je možné uvažovat o těsnějším vztahu mezi zadlužeností/obyv. a velikostí města (a také doplňkově mezi zadlužeností/obyv. a počtem samosprávných obvodů a částí), ale nepotvrdil se žádný vztah mezi zadlužeností /obyv. a fragmentací vlády. K další analýze pomocí chí-kvadrát testu jsme proto již předem přistupovali s jistou skepsí, zda se vůbec potvrdí alespoň závislost zadluženosti/obyv. a velikosti města. Zároveň bylo předem jasné, že velikost zkoumaného vzorku ovlivní výsledek (statutárních měst je 25). A skutečně se ukázalo, že na základě výsledků $\mathrm{s}$ pomocí této metody nemůžeme říci, že zadluženost/obyv. závisí na fragmentaci vlády (zastupitelstva), ale dokonce ani na velikosti města. Tj. lze pouze zůstat u konstatování statisticky významné korelace mezi zadlužeností/obyv. a velikostí města. Alespoň tedy můžeme v souladu s vybranými výsledky jiných studií (Guillamón et al. 2013), (Hájek a Hájková 2009), (Rivers a Yates 1997) říci, že i v podmínkách ČR je velikost statutárního města jedním z faktorů, které jeho zadluženost ovlivňují. 
Pro ČR je spíše pozitivní informací, že se výše uvedenou analýzou neprokázal vliv fragmentace vlády na zadlužení: znamená to, že při rozhodování o hospodaření (a zadlužení) není tolik důležitá př́íslušnost zastupitelů k politickým subjektům, ale racionální zhodnocení situace města. Jako výraz posílení odbornosti a nadstranickosti v práci zastupitelů můžeme považovat i přijímání etických kodexů zastupitelů nad rámec platných zákonných norem.

Výsledky jsou přímo povzbuzením pro opakování podobného výzkumu $\mathrm{v}$ českých podmínkách na jinak definovaném rozsáhlejším souboru obcí - v úvahu připadá nejen soubor všech obcí, ale i výběrový soubor např. obcí s rozšířenou působností nebo s pověřeným obecním úr̆adem. Zde by bylo zajímavé i následné porovnání výsledků za statutární města a za jiný soubor obcí (pozoruhodné by mohlo být zvláště porovnání výsledků za statutární města a obce $s$ rozšíŕenou působností nebo výsledků za obce s rozšířenou působností a obce s pověřeným obecním úrúadem). Dále by bylo možné prozkoumat delší časové období (i když vzhledem k častým změnám legislativy je sporné, nakolik by údaje byly potom srovnatelné). Zcela speciální (a velmi inspirativní) směr výzkumu by potom mohlo být zkoumání vlivu složení zastupitelstva (či rady) dle politických stran a hnutí na zadluženost obcí.

\section{Literatura}

[1] ASHWORTH, J., B. GEYS and B. HEYNDELS, 2005. Government Weakness and Local Public Debt Development in Flemish Municipalities. International Tax and Public Finance, 12(4), 395-422. ISSN 0927-5940.

[2] BALDI, G. and K. STAEHR, 2016. The European debt Crisis and fiscal reactions in Europe 2000-2014. International Economics and Economic Policy, 13(2), 297-317. ISSN 1612-4804.

[3] BASKARAN, T., 2010. On the link between fiscal decentralization and public debt in OECD countries. Public Choice, 145 (3-4), 351-378. E-ISSN 1573-7101.

[4] BOLÍVAR, M., A. GALERA, L. MUŇOS and M. SUBIRÉS, 2014. Factors Influencing Local Government Financial Sustainability: An Empirical Study. Lex Localis, 12(1), 31-54. ISSN 1581-5374.

[5] BOtOC, C., M. PIRTEA and C. NICOLESCU, 2011. Public Debt Sustainability Analysis: EU Case. Annals of the University of Oradea: Economic Science, 1(1), 409415. E-ISSN 1582-5450.

[6] BUCHANAN, J. M., 1998. Veřejné finance v demokratickém systému. Brno: Computer Press. ISBN 80-7226-116-9.

[7] CROPF, R. A. and G. D. WENDEL, 1998. The Determinants of Municipal Debt Policy: a Pooled Time-series Analysis. Environment and Plannning C: Government and Policy, 16(T), 211-224.

[8] GREINER, A., 2012. Public capital, sustainable debt and endogenous growth. Research in Economics, 66(3), 230-238.

[9] GUILlAMÓN, M. D., F. BASTIDA and B. BENITO, 2011. Evalución de la deuda pública local en Espaňa. Revista Espaňola de Financiación y Contabilidad, Apr.-June, 251-285. ISSN 0210-2412.

[10] GUILLAMÓN, M. D., F. BASTIDA and B. BENITO, 2013. The ellectoral budget cycle on municipal policy expenditure. European Journal of Law and Economics, 36(3), 447469. ISSN 0929-1261. 
[11] HÁJEK, P. and V. HÁJKOVÁ, 2009. Debt analysis of Czech municipalities. Scientific papers of the University of Pardubice. Series D, 14, 36-42. E-ISSN 1804-8048.

[12] HOLTZ-EAKIN, D., 1991. Bond Market Conditions and State-Local Capital Spending. National Tax Journal, 44(4), 105-120. ISSN 0028-0283.

[13] KIEWIET, D. R. and K. SZAKATY, 1996. Constitutional Limitations on Borrowing: An Analysis of State Bonded Indebtedness. Journal of Law, Economics and Organization, 12(1), 62-97. ISSN 8756-6222.

[14] MENCINGER, J., A. ARISTOVNIK and M. VERBIC, 2014. The Impact of Growing Public Debt on Economic Growth in The European Union. Amfiteatru Economic, 16(35), 403-414. ISSN 1582-9146.

[15] Ministerstvo financí ČR. Údaje dostupné z: http://www.mfcr.cz. Údaje monitoru MF ČR dostupné z: http://monitor.statnipokladna.cz.

[16] MUSGRAVE, R. A. a P. B. MUSGRAVEOVÁ, 1994. Veřejné finance v teorii a praxi, Praha: Management Press. ISBN 80-85603-76-4.

[17] PRŮCHA, P., 2011. Místní správa. Brno: Masarykova univerzita. ISBN 978-80-2105590-2.

[18] RIVERS, M. J. and B. M. YATES, 1997. City Size and Geographic Segmentation in the Municipal Bond Market. The Quaterly Review of Economics and Finance, 37(3), 633645. ISSN 1062-9769.

[19] RODDEN, J., 2002. The Dilemma of Fiscal Federalism: Grants and Fiscal Performance around the World. American Journal of Political Science, 46(3), 670-687. ISSN 00925853 .

[20] ROUBINI, N. and J. D. SACHS, 1989. Political and Economic determinants of Budget deficits in the Industrial Democracies. European Economic Review, 33(5), 903-939. ISSN 0014-2921.

[21] STAVINS, R. N., A. F. WAGNER and G. WAGNER, 2003. Interpreting sustainability in economic terms: dynamic efficiency plus intergenerational ekvity. Economics Letters, 79(3), 339-343. ISSN 0165-1765.

[22] VEIGA, L. G. and F. J. VEIGA 2007. Political business cycles at the municipal level. Public Choice, 131(1-2), 45-64. E-ISSN 1573-7101.

[23] WEI-TE, E. H., 1995. Revenue Structure and the Size of Government: the Canadian Experience. Public Finance, 50(1), 80-95.

[24] Ústavní zákon č. 1/1993 Sb. Dostupné z: http://www.psp.cz/docs/laws/constitution.html.

[25] Volby v České republice. Dostupné z: http://www.volby.cz.

[26] Zákon č. 128/2000 Sb., o obcích. Dostupné z: https://www.zakonyprolidi.cz/cs/2000128.

[27] Zákon č. 243/2000 Sb., o rozpočtovém určení daní. Dostupné z: https://www.zakonyprolidi.cz/cs/2000-243.

[28] Zákon č. 250/2000 Sb., o rozpočtových pravidlech územních rozpočtů. Dostupné z: https://www.zakonyprolidi.cz/cs/2000-250.

[29] Zákon č. 23/2017 Sb., o pravidlech rozpočtové odpovědnosti. Dostupné z: https://www.zakonyprolidi.cz/cs/2017-23. 